\title{
Toluene biodegradation in an algal-bacterial airlift photobioreactor: influence of the biomass concentration and the presence of an organic phase
}

5 Raquel Lebrero*, Roxana Ángeles, Rebeca Pérez, Raúl Muñoz

6 Department of Chemical Engineering and Environmental Technology, University of 7 Valladolid, Dr. Mergelina, s/n, 47011, Valladolid, Spain. Tel. +34 983186424, Fax: $8+34983423013$.

*Corresponding author: raquel.lebrero@iq.uva.es

Keywords: Airlift bioreactor, algal-bacterial photobioreactor, toluene biodegradation, two-phase partitioning bioreactor

\section{Abstract}

The potential of algal-bacterial symbiosis for off-gas abatement was investigated for the first time by comparatively evaluating the performance of a bacterial (CB) and an algal-bacterial (PB) airlift bioreactors during the treatment of a $6 \mathrm{~g} \mathrm{~m}^{-3}$ toluene laden air emission. The influence of biomass concentration and of the addition of a non-aqueous phase was also investigated. A poor and fluctuating performance was recorded during the initial stages of the experiment, which was attributed to the low biomass concentration present in both reactors and to the accumulation of toxic metabolites. In this sense, an increase in the dilution rate from 0.23 to $0.45 \mathrm{~d}^{-1}$ and in biomass concentration from $\sim 1$ to $\sim 5 \mathrm{~g} \mathrm{~L}^{-1}$ resulted in elimination capacities (ECs) of $300 \mathrm{~g} \mathrm{~m}^{-3} \mathrm{~h}^{-1}$ (corresponding to removal efficiencies $\sim 90 \%$ ). Microalgae activity allowed for a reduction in the emitted $\mathrm{CO}_{2}$ and an increase in dissolved $\mathrm{O}_{2}$ concentration in the PB. However, excess biomass growth over $11 \mathrm{~g} \mathrm{~L}^{-1}$ hindered light penetration and severely decreased photosynthetic activity. The addition of silicone oil at $20 \%$ (on a volume basis) stabilized system performance, leading to dissolved $\mathrm{O}_{2}$ concentrations of $7 \mathrm{mg} \mathrm{L}^{-1}$ and steady ECs of $320 \mathrm{~g} \mathrm{~m}^{-3} \mathrm{~h}^{-1}$ in the PB. The ECs here recorded were considerably higher than those previously reported in toluene-degrading bioreactors. Finally, microbial population analysis by DGGE-sequencing demonstrated the differential specialization of the microbial community in both reactors, likely resulting in different toluene degradation pathways and metabolite production. 


\section{Introduction}

Due to its valuable psychoactive properties, the amount of toluene used in the chemical industry has noticeably increased over the last decades, leading to a concomitant increase in the atmospheric emissions of this aromatic pollutant (WHO 2000, EURART 2003). Toluene causes toxic effects to both human health and the environment, and is considered a priority pollutant by the US-Environmental Protection Agency. Physicalchemical technologies for toluene removal, such as adsorption in activated carbon, thermal incineration or UV oxidation, generate hazardous by-products and/or wastes and entail high investment and operating costs. In this context, bioremediation based on bacterial or fungal activity has arisen as a cost-effective and environmentally sustainable alternative to conventional physical-chemical methods (Harding et al. 2003). In particular, pneumatically agitated suspended-growth systems such as airlift bioreactors have demonstrated a cost-effective toluene abatement performance while avoiding typical operational problems encountered in packed-bed bioreactors: excessive biomass growth, flooding, channeling, pressure drop build-up or formation of anaerobic or dry zones (Vergara-Fdez et al. 2008). Nevertheless, airlift bioreactors for the treatment of toluene still face severe limitations such as (i) a limited pollutant mass transfer from the gas to the liquid phase due to its high Henry law, which results in a low pollutant bioavailability, (ii) microbial inhibition at high toluene inlet concentrations, and (iii) $\mathrm{O}_{2}$ limitation when treating high toluene loads. An enhanced oxygen supply to the microbial community in the reactor by increasing the turbulence of the culture broth might be problematic since intensive mechanical aeration in bioreactors is highly costly and might cause volatilization and re-dispersion of the toluene present in the aqueous phase (Muñoz et al. 2005). 
57 Photosynthetic oxygenation in algal-bacterial photobioreactors constitutes an efficient alternative to conventional aeration methods. In this process, the oxygen photosynthetically produced by microalgae in the presence of light and $\mathrm{CO}_{2}$ is used by heterotrophic bacteria to in situ oxidize the organic pollutant, producing in return the $\mathrm{CO}_{2}$ needed for microalgae photosynthesis. Unlike bacterial processes where the mineralization of organic pollutants releases $\mathrm{CO}_{2}$ and $\mathrm{H}_{2} \mathrm{O}$ as main end-products, microalgal processes are able to fix and recover carbon and other nutrients as valuable biomass besides furnishing $\mathrm{O}_{2}$ to the heterotrophic community. Moreover, some microalgae are capable of biotransforming xenobiotic organic contaminants (Semple et al. 1999; Muñoz and Guieysse 2006). Therefore, microalgae may boost the biodegradation of toluene either by directly biotransforming the pollutant or by enhancing the degradation potential of the microbial community present in the bioreactor. Besides, additional $\mathrm{O}_{2}$ supply by photosynthetic activity might prevent oxygen limitation and accelerate the bacterial degradation of toluene (Semple et al. 1999). Up to date, most studies on toluene biodegradation were based on the activity of bacteria and fungi. On the contrary, microalgae-supported biodegradation of aromatic contaminants has been scarcely investigated, and the catabolic pathways of biodegradation of aromatic compounds in microalgae are still largely unknown. Thus, despite the potential benefits of microalgae-based off-gas treatment, there is no single study comparatively evaluating the performance of algal-bacterial and bacterial bioreactors for the treatment of volatile organic compounds (VOCs).

On the other hand, the limited mass transfer of toluene to the liquid phase might be overcome by the addition to the bioreactor of a non-aqueous phase (NAP) with high affinity for this pollutant, resulting in a so-called two-liquid phase partitioning bioreactor (TLPPB). TLPPBs have been successfully applied to treat both high and low 
82 VOC-laden gas emissions, improving the performance of biological processes (Muñoz et al. 2012, Lebrero et al. 2013). The NAP not only supports an enhanced mass transfer of the target pollutant and $\mathrm{O}_{2}$ from the gas phase to the microorganisms, but also acts as a buffer against surges in pollutant or metabolite concentrations that might be potentially toxic to the microbial community (Lebrero et al. 2015).

This work was devised to comparatively evaluate a bacterial and an algal-bacterial airlift bioreactors treating toluene at high loading rates. The influence of biomass concentration and of the addition of a non-aqueous phase in order to overcome mass transfer limitations and the inhibition resulting from high toluene loads were also investigated. Moreover, the differential specialization of the microbial communities in both bioreactors was also assessed by molecular techniques.

\section{Materials and Methods}

\subsection{Microorganisms and culture conditions}

Both bioreactors were inoculated with a mixture of Chlorella sorokiniana $(0.5 \mathrm{~L})$, activated sludge from Valladolid wastewater treatment plant $(0.1 \mathrm{~L})$ and a toluene acclimated Pseudomonas putida DSM 6899 culture (0.35 L) to an initial total suspended solids concentration (TSS) of $0.79 \mathrm{~g} \mathrm{~L}^{-1}$. The mineral salt medium (MSM) used throughout the entire experiment was composed of $\left(\mathrm{g} \mathrm{L}^{-1}\right): \mathrm{KNO}_{3} 1.25, \mathrm{CaCl}_{2} \cdot \mathrm{H}_{2} \mathrm{O}$ $0.1105, \mathrm{H}_{3} \mathrm{BO}_{3} \quad 0.1142, \mathrm{FeSO}_{4} \cdot 7 \mathrm{H}_{2} \mathrm{O} \quad 0.0498, \mathrm{ZnSO}_{4} \cdot 7 \mathrm{H}_{2} \mathrm{O} \quad 0.0882, \mathrm{MnCl}_{2} \cdot 4 \mathrm{H}_{2} \mathrm{O}$ 0.0144, $\mathrm{MoO}_{3} 0.0071, \mathrm{CuCl}_{2} \cdot 2 \mathrm{H}_{2} \mathrm{O} 0.0157, \mathrm{CoCl}_{2} \cdot 2 \mathrm{H}_{2} \mathrm{O} 0.0049$, EDTA $\left(\mathrm{C}_{10} \mathrm{H}_{16} \mathrm{~N}_{2} \mathrm{O}_{8}\right)$ $0.5, \mathrm{KH}_{2} \mathrm{PO}_{4} 0.6247$ and $\mathrm{K}_{2} \mathrm{HPO}_{4} 1.3251$.

\subsection{Experimental set-up}


106 The experimental plant consisted of two identical internal-loop airlift glass bioreactors

107 with a total volume of $2.5 \mathrm{~L}$ and a working volume of $2.2 \mathrm{~L}$, operated in parallel in an

108 air-conditioned room at a constant temperature of $25^{\circ} \mathrm{C}$ (Figure 1). The inner tube had a

109 diameter of $0.055 \mathrm{~m}$ and a height of $0.295 \mathrm{~m}$, while the external cylinder diameter and

110 height were $0.09 \mathrm{~m}$ and $0.42 \mathrm{~m}$, respectively. A porous metallic diffuser, with an

111 average pore diameter of $2 \mu \mathrm{m}$, was placed at the bottom of the inner tube to promote

112 gas distribution. The air-lift photobioreactor (PB) was continuously illuminated with

113 LED lamps arranged concentrically at an average intensity of $330.5 \mu \mathrm{mol} \mathrm{m}^{-2} \mathrm{~s}^{-1}$ (within

114 the optimum range for the photosynthetic apparatus of microalgae, Muñoz and Guieysse

115 2006), while the control air-lift (CB) was covered with an opaque structure to prevent

116 diffuse light penetration.

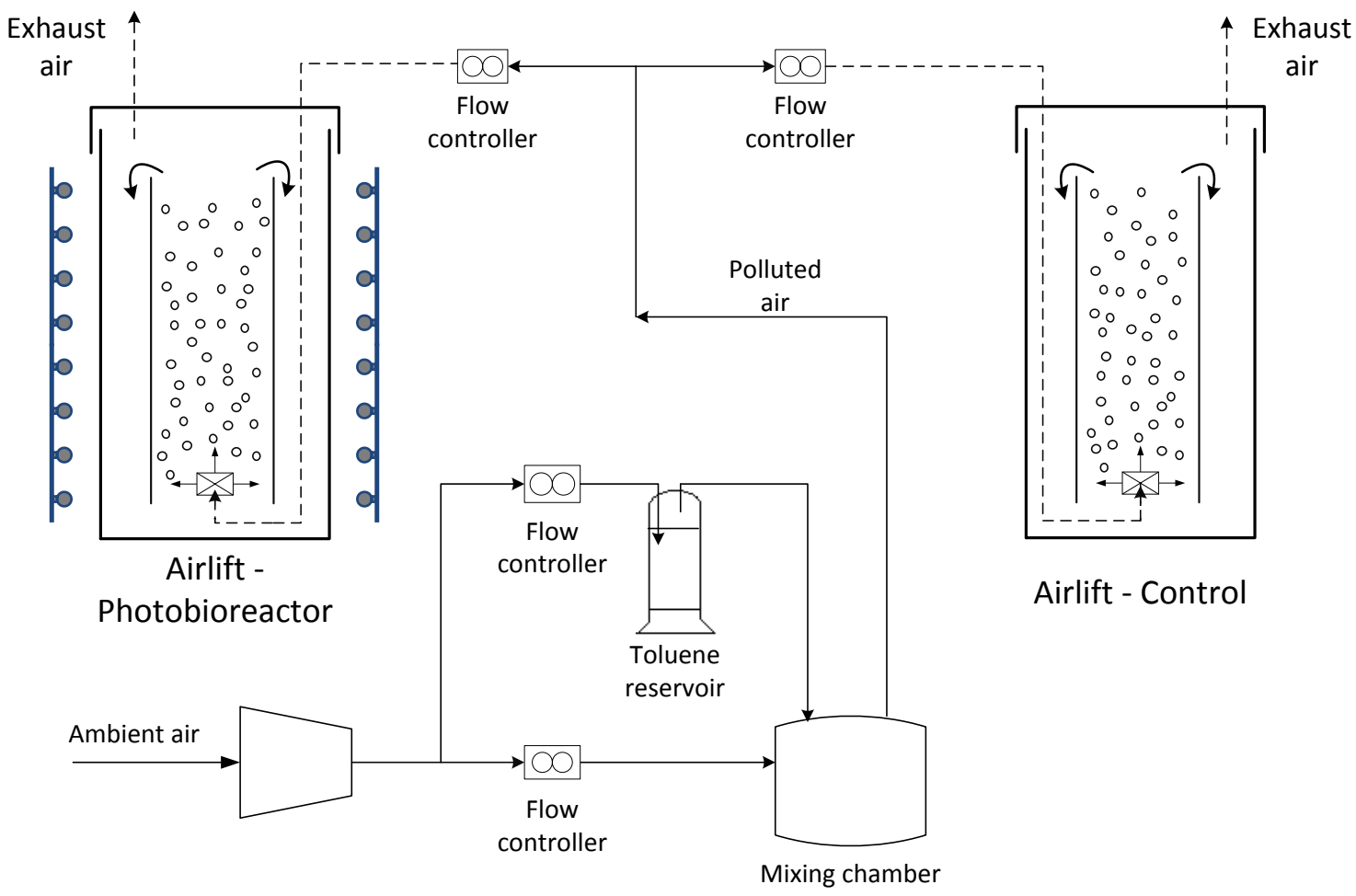

Figure 1. Schematic representation of the experimental set-up 
120 The toluene-contaminated stream was obtained by sparging ambient air (flow controller, 121 Aalborg, USA) in a reservoir containing liquid toluene kept at a constant temperature of $12225 \pm 2{ }^{\circ} \mathrm{C}$. The toluene-laden stream was then diluted with ambient air in a mixing 123 chamber and subsequently divided into two identical streams (flow controller, Aalborg, 124 USA) to feed both air-lift reactors. The toluene inlet concentration was maintained at $1256.2 \pm 0.7 \mathrm{~g} \mathrm{~m}^{-3}$ and the reactors were operated at an empty bed residence time of $\sim 1.1$ 126 min (corresponding to an inlet load of $369 \pm 45 \mathrm{~g} \mathrm{~m}^{-3} \mathrm{~h}^{-1}$ ).

\subsection{Operational procedure}

During the first 6 days of operation, $0.5 \mathrm{~L}$ of the culture broth were daily removed from each bioreactor and replaced by fresh MSM. From day 6 to 26, the exchange of culture medium was increased to $1 \mathrm{~L}$ in order to avoid metabolite accumulation, which resulted in low TSS concentrations in both reactors. Therefore, $0.5 \mathrm{~L}$ of the $1 \mathrm{~L}$ culture broth daily replaced were centrifuged and the biomass returned to the corresponding reactor from day 26 on. This strategy allowed controlling the biomass concentration and investigating the effect of this parameter on toluene removal performance. From day 46 onwards, the biomass recovered by centrifugation was increased to that corresponding to $0.9 \mathrm{~L}$ of the retrieved culture broth. Weekly cleanings were performed from day 14 to remove any biomass attached to the reactor walls. Finally, $20 \%$ of the culture broth was substituted by silicone oil $200 \mathrm{cSt}$ (Sigma Aldrich, USA) at day 82 in order to improve process robustness.

141 Inlet and outlet gas concentrations of toluene and $\mathrm{CO}_{2}$ were daily measured in both 142 bioreactors. The $\mathrm{pH}$, temperature and dissolved oxygen (DO) were daily recorded from 143 the culture broths. Three times per week, samples from the culture broth were also taken 144 to determine the concentration of TSS, total organic carbon (TOC) and total nitrogen 
145 (TN) in both bioreactors. By day 68, samples from the liquid phase of each bioreactor 146 were taken and analyzed in duplicate by SPME-GC-MS in order to assess the presence 147 of any secondary metabolite accumulated in the culture broth.

148 Finally, six samples for microbial analysis were collected and stored immediately at $149-20^{\circ} \mathrm{C}$. Samples 1 and 2 corresponded to the CB and the PB inoculum, respectively. 150 The rest of the samples were retrieved at the end of the experiment (day 106) from the 151 suspended biomass in the CB (sample 3) and the PB (sample 4), and from the biomass 152 attached to the reactor walls in the CB (sample 5) and the PB (sample 6).

\subsection{Analytical methods}

155 Toluene gas concentration was measured using a Varian 3900 gas chromatograph (Palo 156 Alto, USA) equipped with a flame ionization detector and a SupelcoWax capillary 157 column $(15 \mathrm{~m} \times 0.25 \mathrm{~mm} \times 0.25 \mu \mathrm{m})$. The injector, detector and oven temperatures were set at 210,250 and $140{ }^{\circ} \mathrm{C}$, respectively. $\mathrm{CO}_{2}$ concentration was determined in a Bruker 430 gas chromatograph (Palo Alto, USA) coupled with a thermal conductivity detector and equipped with a CP-Molsieve 5A $(15 \mathrm{~m} \times 0.53 \mu \mathrm{m} \times 15 \mu \mathrm{m})$ and a CPPora-BOND Q $(25 \mathrm{~m} \times 0.53 \mu \mathrm{m} \times 10 \mu \mathrm{m})$ columns. The oven, injector and detector 162 temperatures were maintained at 45,150 and $175^{\circ} \mathrm{C}$, respectively.

163 Temperature and DO concentration in the culture broth of both reactors were monitored 164 by an OXI 330i oximeter (WTW, Germany). The $\mathrm{pH}$ of the liquid samples was 165 determined by a pH meter Crison $5012 \mathrm{~T}$ (Crison Instruments, Spain), while biomass 166 concentration was measured as TSS according to Standard Methods (American Water 167 Works Association, 2012). Samples for the determination of TOC and TN concentrations were filtered through $0.22 \mu \mathrm{m}$ filters (Merck Millipore, USA) prior to 
analysis in a TOC-VCSH analyzer (Shimadzu, Japan) coupled with a

170 chemiluminescense detection TN module (TNM-1) (Shimadzu, Japan).

171 The presence of secondary metabolites in the culture broth was analyzed as follows:

172 1.7-mL glass vials were filled with $1.5 \mathrm{~mL}$ of the culture broth sample and closed with

173 Teflon/rubber caps. Samples were pre-concentrated by SPME by immersing an $85-\mu m$

174 Carboxen/PDMS fibre (Supelco, Bellefonte, USA) into the leachate for $5 \mathrm{~min}$. The

175 SPME fibre was then injected and allowed to desorb for $1 \mathrm{~min}$ in an Agilent $6890 \mathrm{~N}$

176 GC-MS equipped with a DB-WAX column $(30 \mathrm{~m} \times 0.250 \mathrm{~mm} \times 0.25 \mu \mathrm{m})(\mathrm{J} \& \mathrm{~W}$

177 Scientific ${ }^{\circledR}, \mathrm{CA}$, USA). The injector temperature was set at $200{ }^{\circ} \mathrm{C}$ while the oven

178 temperature was initially maintained at $40{ }^{\circ} \mathrm{C}$ for $4 \mathrm{~min}$ and then increased at

$17910{ }^{\circ} \mathrm{C} \min ^{-1}$ up to $200{ }^{\circ} \mathrm{C}$. Source and MS quadrupole temperatures were set at 230 and

$180150{ }^{\circ} \mathrm{C}$, respectively. Only compounds with a match quality $\geq 90 \%$ were considered in 181 the discussion.

182

183

2.5 Microbiological procedures

184 Genomic DNA was extracted using the protocol described in the Fast ${ }^{\circledR}$ DNA Spin Kit

185 for Soil (MP Biomedicals, LLC) handbook. The V6-V8 region of the bacterial 16S

186 rRNA genes was amplified by polymerase chain reaction (PCR) using the universal

187 bacterial primers 968-F-GC and 1401-R (Sigma-Aldrich, St. Louis, MO, USA). The

188 PCR mixture contained $1 \mu \mathrm{L}$ of each primer (10 ng $\mu \mathrm{L}^{-1}$ each primer), $25 \mu \mathrm{L}$ of

189 BIOMIX ready-to-use 2 reaction mix (Bioline, Ecogen), $2 \mu \mathrm{L}$ of the extracted DNA,

190 and Milli-Q water up to a final volume of $50 \mu \mathrm{L}$. The PCR thermo-cycling program

191 consisted of 2 min of pre-denaturation at $95^{\circ} \mathrm{C}, 35$ cycles of denaturation at $95^{\circ} \mathrm{C}$ for 30 
$192 \mathrm{~s}$, annealing at $56^{\circ} \mathrm{C}$ for $45 \mathrm{~s}$, and elongation at $72^{\circ} \mathrm{C}$ for $1 \mathrm{~min}$, with a final 5-min 193 elongation at $72^{\circ} \mathrm{C}$.

194 The DGGE analysis of the amplicons was performed with a D-Code Universal Mutation

195 Detection System (Bio Rad Laboratories) using $8 \%$ (w/v) polyacrylamide gels with a 196 urea/formamide denaturing gradient of 45 to $65 \%$. DGGE running conditions were 197 applied according to Roest et al. (2005). The gels were stained with GelRed Nucleic 198 Acid Gel Stain (biotium) for $1 \mathrm{~h}$. The most relevant bands were excised from the DGGE 199 gel in order to identify the bacteria present in the samples, resuspended in $50 \mu \mathrm{L}$ of 200 ultrapure water and maintained at $60{ }^{\circ} \mathrm{C}$ for $1 \mathrm{~h}$ to allow DNA extraction from the gel. 201 A volume of $5 \mu \mathrm{L}$ of the supernatant was used for reamplification with the original 202 primer set. Before sequencing, PCR products were purified with the GenElute PCR 203 DNA Purification Kit (Sigma-Aldrich, St. Louis, MO, USA).

204 DGGE profiles were compared using the GelCompar IITM software (Applied Maths 205 BVBA, Sint-Martens-Latem, Belgium). After image normalization, bands were defined 206 for each sample using the bands search algorithm within the program. The peak heights 207 in the densitometric curves were also used to determine the diversity indices based on 208 the Shannon-Wiener diversity index $(\mathrm{H})$, calculated as follows:

$$
H=-\sum\left[P_{i} \ln \left(P_{i}\right)\right]
$$

210 where $\mathrm{H}$ is the diversity index and $\mathrm{Pi}$ is the importance probability of the bands in a lane $211\left(\mathrm{Pi}=\mathrm{n}_{\mathrm{i}} / \mathrm{n}\right.$, where $\mathrm{n}_{\mathrm{i}}$ is the height of an individual peak and $\mathrm{n}$ is the sum of all peak 212 heights in the densitometric curves). Therefore, this index reflects both the sample 213 richness (relative number of DGGE bands) and evenness (relative intensity of every 214 band). 
215 Similarity indices of the compared samples were calculated from the densitometric 216 curves of the scanned DGGE profiles by using the Pearson product-moment correlation 217 coefficient (Häne et al. 1993). The taxonomic position of the sequenced DGGE bands 218 was obtained using the RDP classifier tool (50\% confidence level) (Wang et al. 2007). 219 The closest cultured and uncultured relatives to each band were obtained using the 220 BLAST search tool at the NCBI (National Centre for Biotechnology Information) 221 (McGinnis and Madden 2004). The sequences generated from this work are deposited in 222 GenBank under accession numbers KT200332-KT200347.

\section{Results and Discussion}

\subsection{Bacterial and algal-bacterial airlifts performance}

A different performance was observed during the start-up of both bioreactors despite following the same inoculation procedure. Whereas toluene removal efficiency (RE) peaked at $99 \%$ immediately after start-up in the control bioreactor, decreasing afterwards to $\sim 16 \%$ by day 5 , a maximum RE of $50 \%$ was recorded by day 3 of operation in the photobioreactor, gradually decreasing to zero by day 5 (Figures $2 \mathrm{a}$ and dilution rate of $0.45 \mathrm{~d}^{-1}$ ) and maintained during the second operational stage. However, a consistent low toluene biodegradation performance was recorded in both bioreactors this sense, toluene REs fluctuated from 17 to $90 \%$ in the PB and from 58 to $87 \%$ in the CB between days 15 and 26, the maximum elimination capacities (ECs) being recorded immediately after biomass detachment from the reactor walls in both systems (Figures 2 
240 and 3). During these first and second operational stages, biomass concentration

241 increased from $0.8 \mathrm{~g} \mathrm{~L}^{-1}$ to $4 \mathrm{~g} \mathrm{~L}^{-1}$ in the $\mathrm{PB}$ and to $2.2 \mathrm{~g} \mathrm{~L}^{-1}$ in the $\mathrm{CB}$ as a result of an

242 enhanced toluene degradation (Figure 4).

a

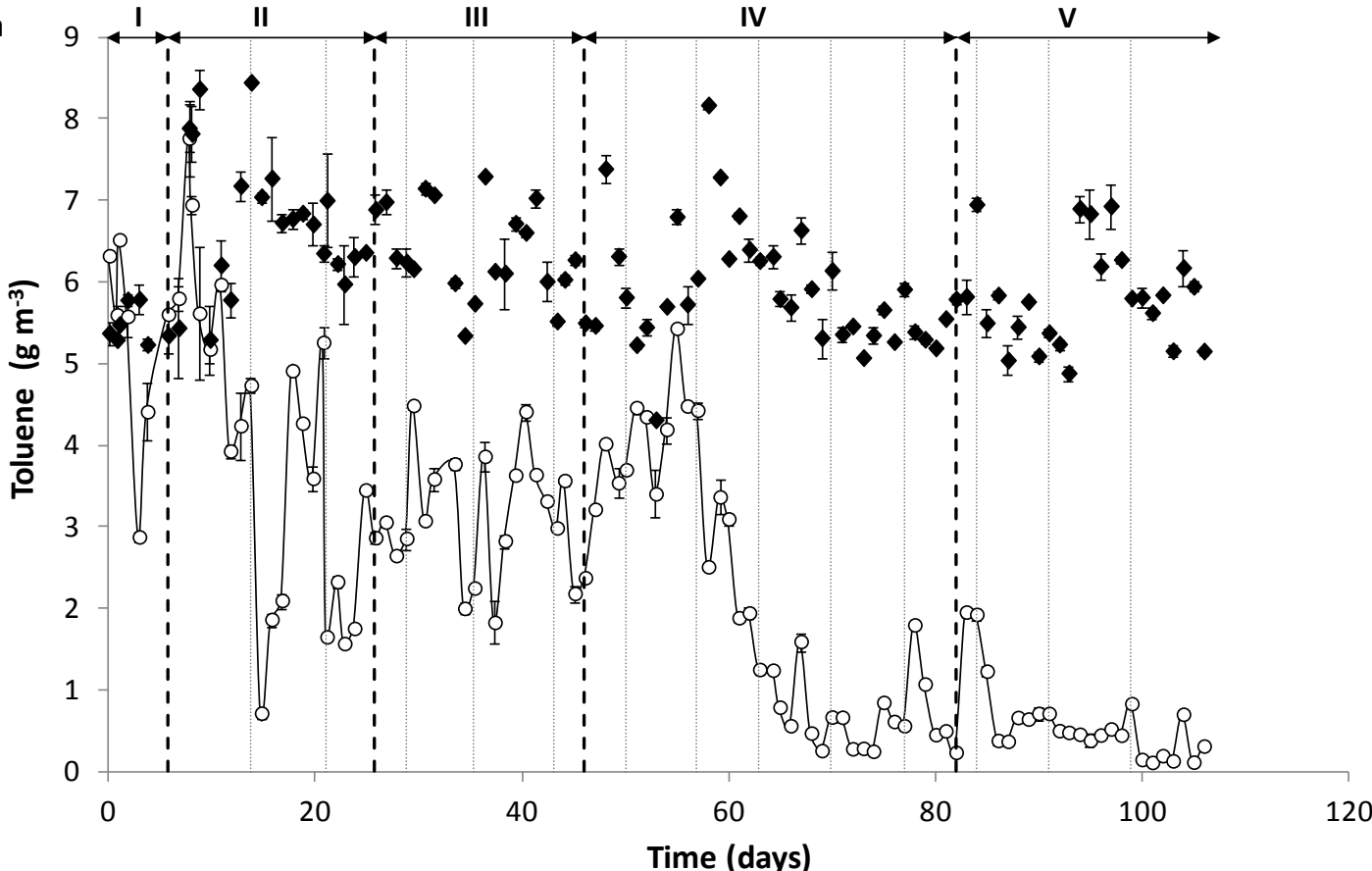

b

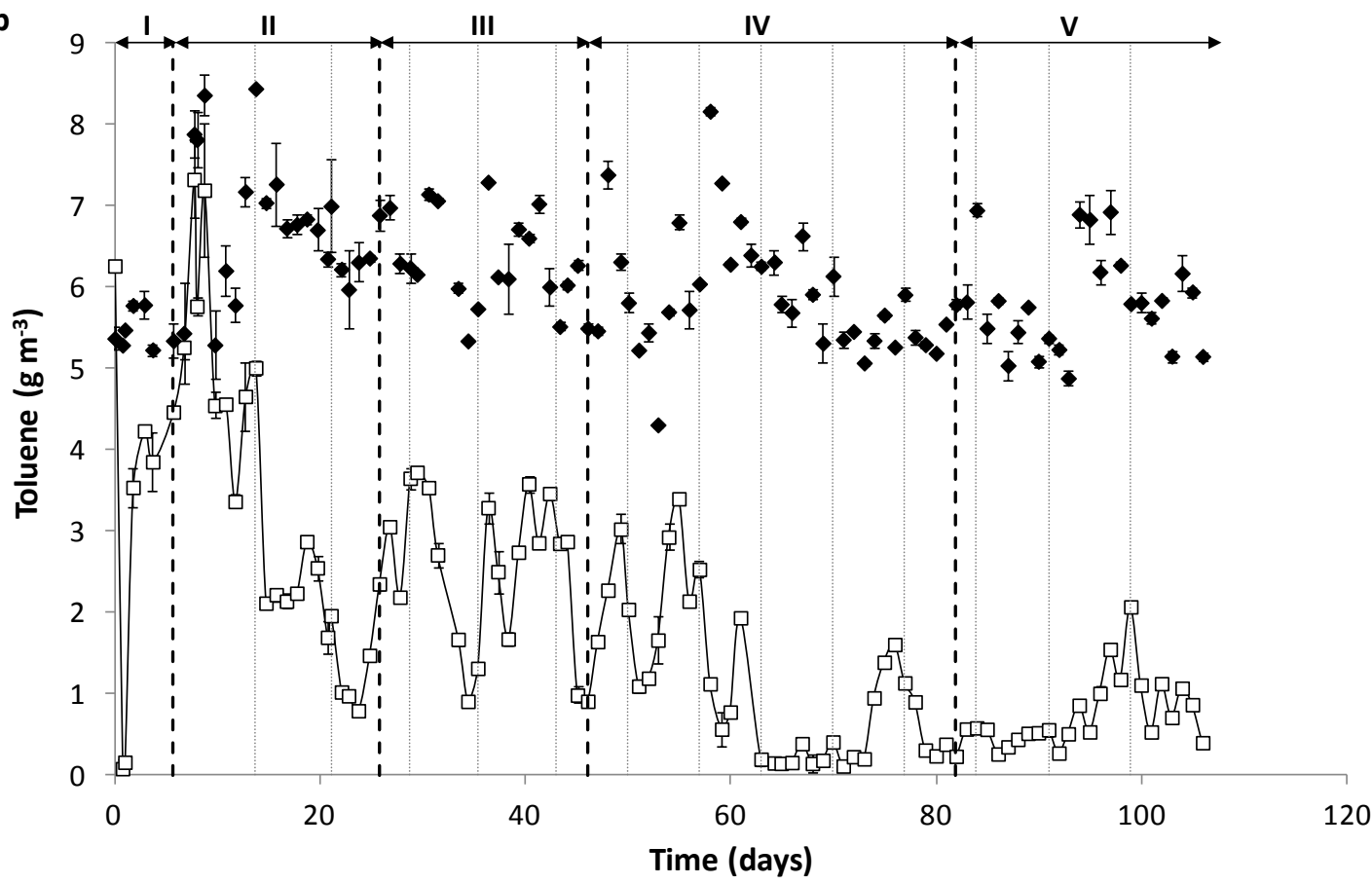

Figure 2. Time course of toluene inlet $(\checkmark)$ and outlet concentration in (a) the photobioreactor represent the reactor cleanings and dashed lines the different operating stages as indicated in the 

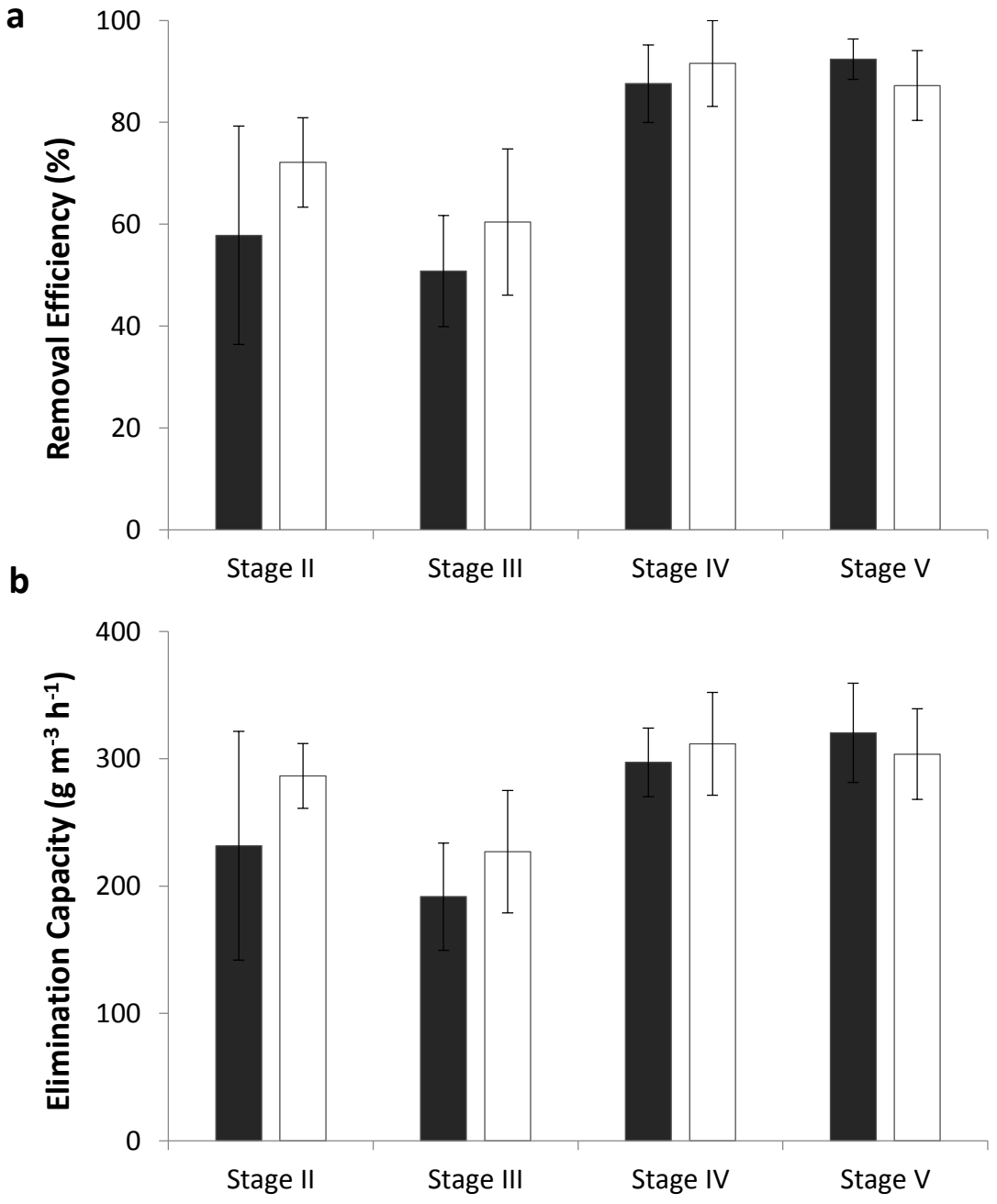

Figure 3. Average removal efficiency (a) and elimination capacity (b) recorded in the photobioreactor (black columns) and control airlift reactor (white columns) in the different operating stages. Vertical bars represent standard deviations.

The concentration of $\mathrm{CO}_{2}$ also increased concomitantly with toluene removal, with average values (days 20-25) of $14.0 \pm 0.6 \mathrm{~g} \mathrm{~m}^{-3}$ in the $\mathrm{CB}$ and of $3.1 \pm 0.8 \mathrm{~g} \mathrm{~m}^{-3}$ in the PB. These lower $\mathrm{CO}_{2}$ emissions in the PB confirmed the intense photosynthetic activity (Figure 5a). The dissolved $\mathrm{O}_{2}$ concentration recorded during stage II was also higher in the $\mathrm{PB}\left(5.9 \pm 0.8 \mathrm{mg} \mathrm{L}^{-1}\right)$ than in the $\mathrm{CB}\left(0.4 \pm 0.1 \mathrm{mg} \mathrm{L}^{-1}\right)$ as a result of microalgal photosynthesis (Figure 5b). The unstable performance observed in both reactors during stage II (days 5-26) was attributed to the inhibition of microbial activity mediated by the accumulation of toxic metabolites and to the progressive accumulation of biomass in the 
261 reactor walls, resulting in a low suspended biomass concentration. In this sense,

262 biomass detachment from the reactor walls led to a higher suspended biomass

263 concentration, which entailed a one-off increase in the removal efficiency. This increase

264 in toluene removal resulted in higher metabolites concentrations and therefore in a

265 subsequent decrease in the reactor performance, which was again restored after the

266 following cleaning. Nevertheless, along this second stage, biomass accumulation

267 globally resulted in higher toluene REs. Several authors have previously highlighted the

268 key role of biomass concentration and metabolites accumulation on microbial instability

269 in bioprocesses treating toluene (Bordel et al. 2007, Díaz et al. 2008). In this context,

270 Díaz et al. (2008) observed that restoration of system performance after the

271 accumulation of inhibitory metabolites in a suspended growth reactor treating toluene

272 was not immediate likely due to the deterioration of the toluene degrading community.

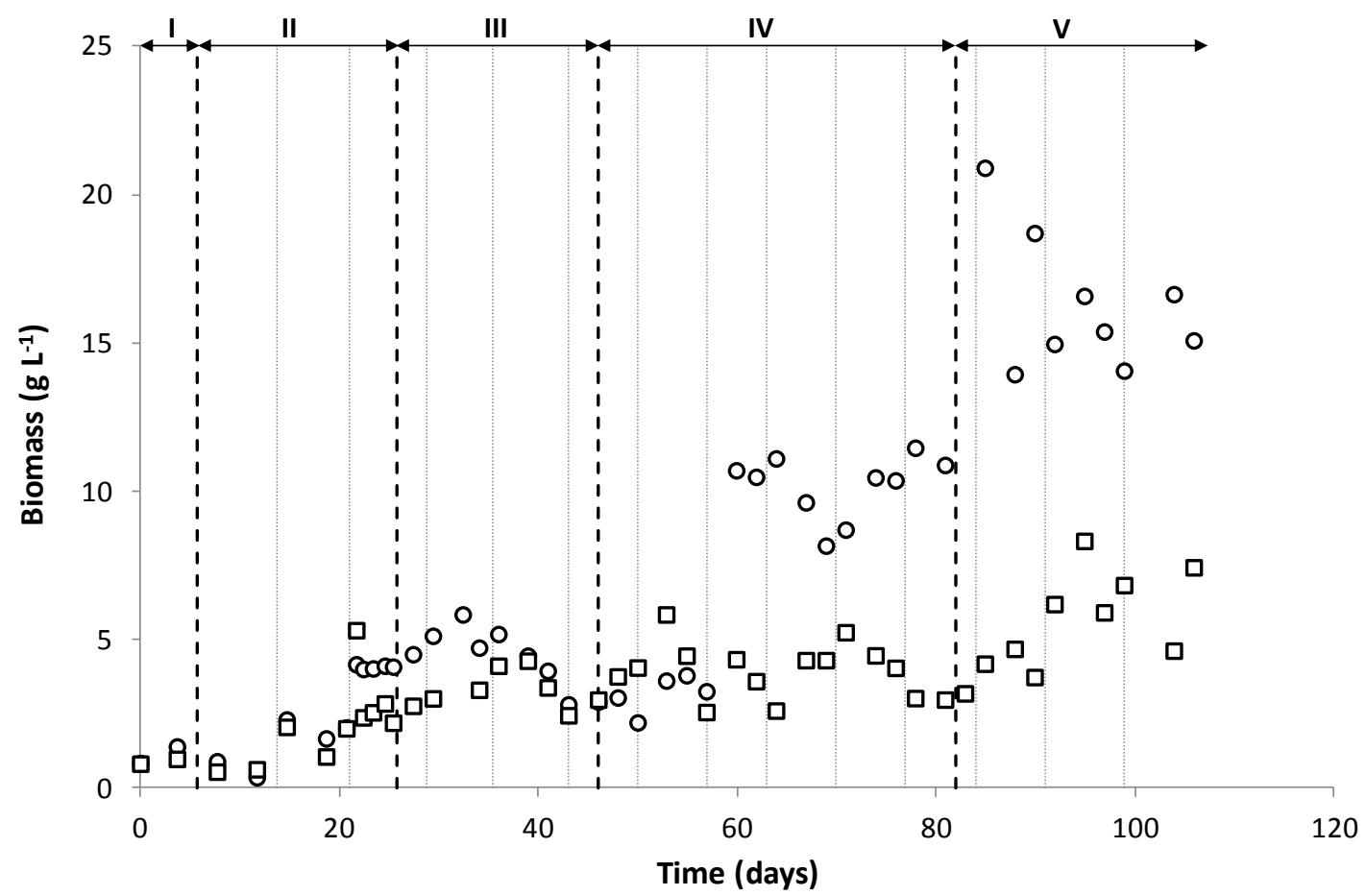

Figure 4. Time course of the biomass concentration as total suspended solids concentration in 
277 At this point, it was evident that microbial activity was limiting toluene abatement in 278 both bioreactor configurations. Thus, half of the exchanged media was daily centrifuged 279 and the biomass returned to the corresponding reactor during stage III in order to further 280 increase the suspended solids concentration in the reactors. This operational strategy 281 initially resulted in a TSS increase up to 5.8 and $4.3 \mathrm{~g} \mathrm{~L}^{-1}$ in the PB and CB, 282 respectively, both concentrations stabilizing at $\sim 2.9 \mathrm{~g} \mathrm{~L}^{-1}$ by day 46 (Figure 4 ). During 283 this stage, average toluene removals of $51 \pm 11 \%$ in the PB and $60 \pm 14 \%$ in the CB 284 were recorded. Despite the enhancement in toluene abatement mediated by the increase 285 in biomass concentration, both bioreactors still exhibited a highly fluctuating 286 performance (Figures 2 and 3). A lower $\mathrm{CO}_{2}$ concentration was also recorded along 287 stage III in the PB compared to that of the CB, although a gradual decrease in the 288 photosynthetic activity was observed from day 37. This deterioration in microalgae 289 activity resulted in higher $\mathrm{CO}_{2}$ outlet concentrations and lower dissolved oxygen values 290 in the PB $\left(9.1 \pm 0.9 \mathrm{~g} \mathrm{~m}^{-3}\right.$ and $0.2 \pm 0.1 \mathrm{mg} \mathrm{L}^{-1}$, respectively) (Figure 5). Unfortunately, 291 this behavior could not be attributed to any macroscopic change in the photobioreactor.

292 From day 46 onwards (stage IV), $90 \%$ of the retrieved culture broth was centrifuged in 293 order to recover and return the biomass to both bioreactors. While this procedure 294 resulted in a significant biomass accumulation in the photobioreactor $\left(10.2 \pm 1.1 \mathrm{~g} \mathrm{~L}^{-1}\right.$ 295 by day 60), the TSS value remained at $3.9 \pm 0.8 \mathrm{~g} \mathrm{~L}^{-1}$ in the control airlift (Figure 4). 296 Stabilization in the abatement performance at REs of $87.6 \pm 7.6 \%$ and $91.6 \pm 8.4 \%$ 297 was observed from day 63 onwards in the $\mathrm{PB}$ and the $\mathrm{CB}$, respectively, corresponding 298 to ECs of $297.1 \pm 26.9$ and $311.7 \pm 40.4 \mathrm{~g} \mathrm{~m}^{-3} \mathrm{~h}^{-1}$. These high toluene removals resulted 299 in a decrease in the DO values in both reactors. Under these operational conditions, 300 photosynthetic activity in the $\mathrm{PB}$ was severely deteriorated as shown by the outlet $\mathrm{CO}_{2}$ 301 concentrations in the PB $\left(16.5 \pm 2.4 \mathrm{~g} \mathrm{~m}^{-3}\right)$ compared to those recorded in the $\mathrm{CB}(20.1$ 
$302 \pm 2.1 \mathrm{~g} \mathrm{~m}^{-3}$ ) under comparable REs. At this point, it is important to stress that biomass

303 concentration in the PB is not only a key parameter governing pollutant removal rate,

304 but also determining the light utilization efficiency by microalgae. In this sense, no

305 further increase in photosynthetic oxygenation rate occurs above a critical biomass

306 concentration due to mutual shading and algal dark respiration as demonstrated by

307 Muñoz et al. (2004). This deterioration in photosynthetic activity was correlated to the

308 increase in biomass concentration in the PB by day 60, which likely hindered light

309 penetration with the concomitant reduction in microalgae $\mathrm{CO}_{2}$-fixation capacity.

310 In order to identify the different metabolites present in the culture broth, samples from

311 the liquid phase of each bioreactor were taken at day 68 and analyzed in duplicate by

312 SPME-GC-MS. Despite the limitation of this technique due to the hydrophobic nature

313 of the PDMS fibre (which only allowed the detection of non-water soluble compounds),

314 significant differences were observed between both culture broths. For instance, among

315 the aromatic and alcohol derivative compounds detected, oxyme- methoxy- phenyl

316 benzene was retrieved from both samples, while 1,2 benzene dicarboxylic acid was only

317 found in the CB and 2- (2-ethoxyethoxy) ethanol was the most significant metabolite in

318 the PB. $\alpha$-dimethylamino 4-ethoxy o-cresol was only detected in the photobioreactor

319 airlift. These results suggested the occurrence of different toluene degradation pathways

320 depending on the microbial community, thus resulting in the accumulation of different

321 extracellular metabolites. 


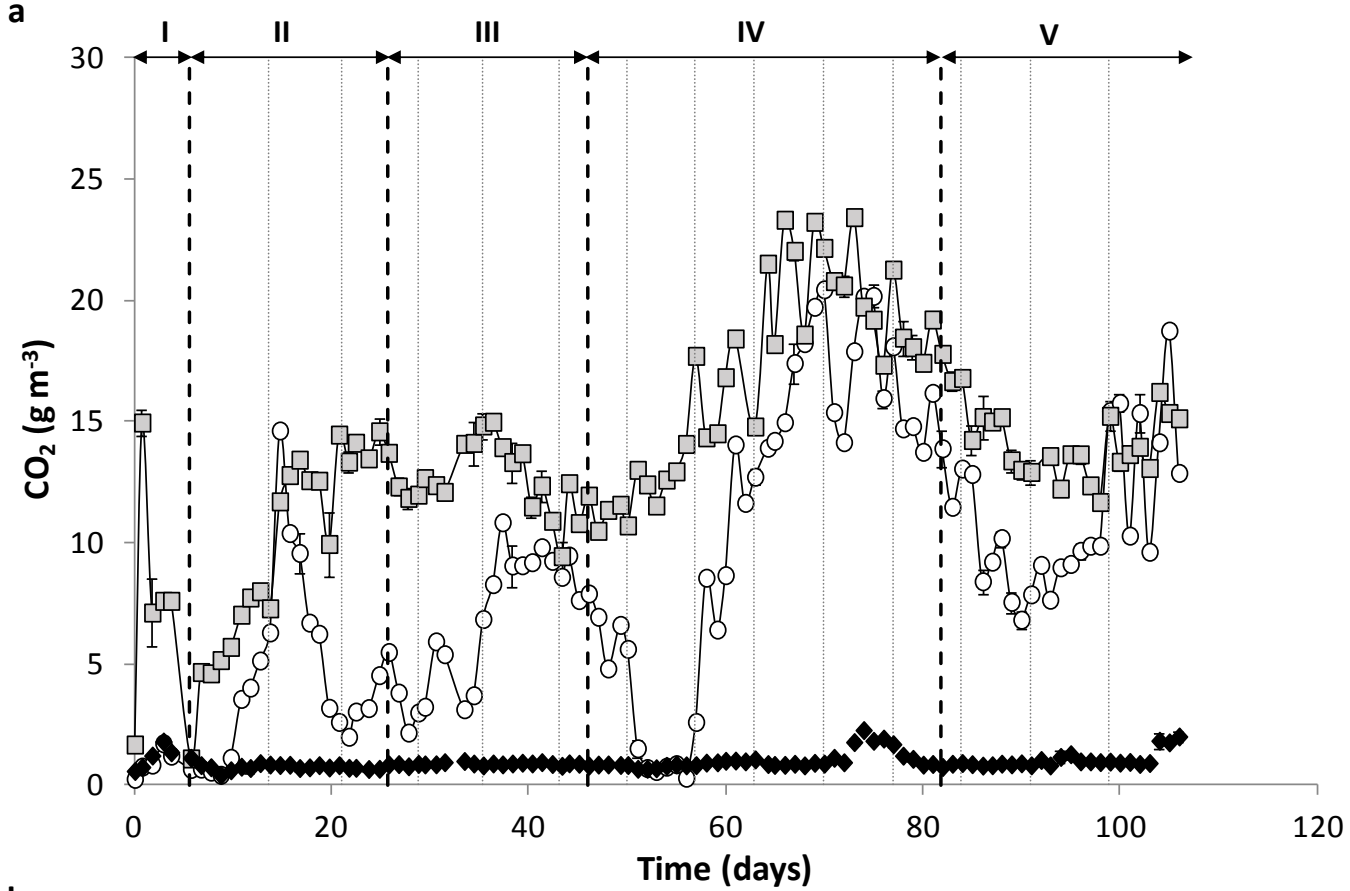

b

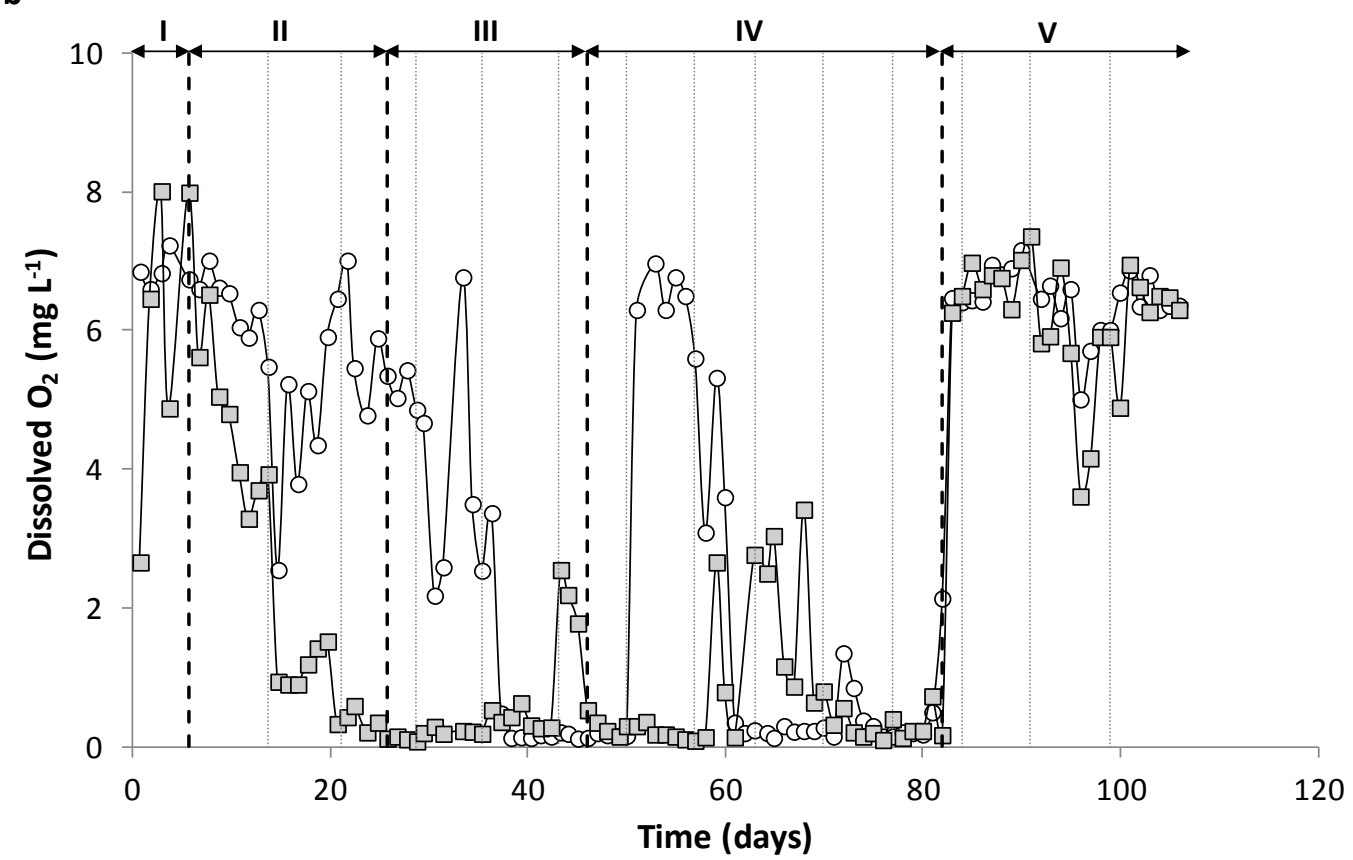

Figure 5. Time course of (a) $\mathrm{CO}_{2}$ inlet $(\checkmark)$ and outlet concentration in the photobioreactor (O) and control reactor $(\square)$; (b) dissolved oxygen concentration in the photobioreactor $(\circ)$ and control reactor $(\square)$. Dotted lines represent the reactor cleanings and dashed lines the different operating stages as indicated in the upper part of each graph.

328 Finally, the addition of silicone oil supported an increase in the DO concentration in 329 both reactors (Figure 5b). The removal performance of the photobioreactor experienced 330 both a slight increase and a stabilization at $92.4 \pm 4.0 \%\left(\mathrm{EC}=320.4 \pm 38.9 \mathrm{~g} \mathrm{~m}^{-3} \mathrm{~h}^{-1}\right)$, 
331 while biomass accumulated up to $\sim 15 \mathrm{~g} \mathrm{~L}^{-1}$. Steady REs (except for a sudden decrease

332 by day 99) of $87.2 \pm 6.9 \%$ were recorded in the control airlift during this last stage 333 (corresponding to an EC $=303.6 \pm 35.6 \mathrm{~g} \mathrm{~m}^{-3} \mathrm{~h}^{-1}$ ), together with an increase in biomass 334 concentration up to $5.6 \pm 2.7 \mathrm{~g} \mathrm{~L}^{-1}$. Several authors have demonstrated a mass transfer 335 enhancement of poorly water soluble compounds (as is the case of toluene and oxygen, 336 with Henry constants $\mathrm{H}=\mathrm{Ca} / \mathrm{Cg}$ of 3.7 and 0.03 , respectively (Sander 2014)) when a 337 non-aqueous phase such as silicone oil is added to the bioreactor. This enhanced toluene 338 mass transfer was not only related with the higher solubility of the toluene in the 339 silicone oil, but also with an enhanced gas/water interfacial area (Quijano et al. 2010, 340 Lebrero et al. 2013). Moreover, the addition of this non-aqueous phase to the 341 bioreactors acted as a metabolite reservoir, thus avoiding inhibitory concentrations in 342 the culture broth.

The ECs here recorded were considerably higher than those reported in toluene344 degrading biofilters, ranging from 90 up to $165 \mathrm{~g} \mathrm{~m}^{-3} \mathrm{~h}^{-1}$ at toluene inlet concentrations 345 of 0.4-8 $\mathrm{g} \mathrm{m}^{-3}$ (Jorio et al. 1998, Singh et al. 2010, Gallastegui et al. 2013, Cheng et al. 346 2016). These ECs were also higher than previous experiments performed in airlift 347 bioreactors. Vergara-Fernandez et al. (2008) reported maximum ECs of $230 \mathrm{~g} \mathrm{~m}^{-3} \mathrm{~h}^{-1}$ at $348 \sim 8 \mathrm{~g} \mathrm{~m}^{-3}$ of toluene, while Harding et al. (2003) only achieved $35 \mathrm{~g} \mathrm{~m}^{-3} \mathrm{~h}^{-1}$ in an 349 external loop airlift fed with $15 \mathrm{~g} \mathrm{~m}^{-3}$ of toluene. Airlift bioreactors are a cost-effective 350 alternative for the implementation of aerobic off-gas treatment processes compared to 351 packed-bed bioreactors, besides providing a better process control. The high toluene 352 removal performance here achieved, together with its inherently low energy 353 consumption, support the applicability of this pneumatically aerated configuration. 354 Moreover, the presence of a microalgae community in the PB showed a beneficial effect 355 during stage II by reducing the amount of $\mathrm{CO}_{2}$ emitted to the atmosphere compared to 
356 that of the CB concomitantly with an increase in the DO concentration in the cultivation

357 media. Finally, the operation of the airlift as a two-phase partitioning reactor with the

358 addition of silicone oil further enhanced not only toluene but also oxygen mass transfer,

359 thus preventing $\mathrm{O}_{2}$ limiting scenarios.

\subsection{Microbial analysis}

362 The Shannon-Wiener diversity indices obtained showed that the high diversity of the 363 inoculum was maintained throughout the experiment despite the selective pressure of 364 toluene and its metabolites (Figure 6). This diversity index, with typical values ranging 365 from 1.5 to 3.5 (low and high species evenness and richness, respectively) (McDonald 2003) was similar for all the samples retrieved, varying from 2.33 (biomass attached onto the $\mathrm{PB}$ ) to a highest value of 2.94 corresponding to the inoculum and the biomass attached in the CB. As expected, a low Pearson similarity value of $32.4 \%$ was recorded between the suspended biomass samples of both bioreactors, although the attached biomass retrieved from the $\mathrm{CB}$ and the $\mathrm{PB}$ showed a similarity of $74.9 \%$.

371 From the DGGE gel, 16 bands were sequenced (Figure 6, Table 1), rendering six 372 different phyla: Proteobacteria (eight bands), Acidobacteria (four bands), 373 Cyanobacteria/Chloroplast (one band), Ignavibacteriae (one band), Actinobacteria (one band) and Chloroflexi (one band). The closest cultured and uncultured relatives of each band were determined by NCBI BLAST analysis and summarized in Table 1 along with the environment from which the closest organisms were retrieved. The VOC

377 biodegradation capacity of some of the microorganisms here identified has been already 378 reported in the literature. For instance, from the bands retrieved in both bioreactors, 379 bacteria from the genus Xanthobacter flavus (band 7) and Bryobacter (band 11) within the phylum Proteobacteria are able to degrade phenol (Nagamani et al. 2009), while 
381 members of the family Enterobacteriaceae (band 8) have been found to transform

382 aromatics under both aerobic and anaerobic conditions, tolerating and removing 383 different polycyclic aromatic hydrocarbons (Toledo et al. 2006). Microorganisms from 384 the genus Ignavibacterium (phylum Ignavibacteriae) (band 14) and from the phylum 385 Chloroflexi (band 16) have been also retrieved from toluene treatment systems (Lebrero 386 et al. 2012, Kuppardt et al. 2014). Six of the DGGE sequenced fragments were only 387 found in the $\mathrm{CB}(1,3,5,6,12$ and 15), from which bands 6 (order Rhizospirales, 388 phylum Proteobacteria) and 15 (genus Mycobacterium, phylum Actinobacteria) were 389 also identified as PAH and BTEX degrading microorganisms, respectively (Martin et al. 390 2012, Zhang et al. 2013). Finally, DGGE fragments 9, 10 and 13 were only retrieved 391 from the PB. In particular, band 13 was identified as Chlorella Sorokiniana, with a 392 higher relative abundance in the suspended biomass sample. Blastocatella-like bacteria 393 (bands 9 and 10), commonly found in biological systems treating petrochemical 394 effluents, likely played a key role in toluene degradation in the photobioreactor based on 395 the intensity of the DGGE bands (Yang et al. 2015, Fu et al. 2016). 
397 Figure 6. DGGE profile of the main bacterial communities present in the CB inoculum (1), PB 398 inoculum (2), suspended biomass at day 106 in the CB (3) and the PB (4), and attached biomass 399 at day 106 in the CB (5) and PB (6). The Shannon-Wiener diversity indexes are indicated in the 400 401

\begin{tabular}{|cccccc|}
\hline 1 & 2 & 3 & 4 & 5 & 6 \\
\hline 2.6 & 2.9 & 2.6 & 2.6 & 2.9 & 2.3 \\
\hline
\end{tabular}

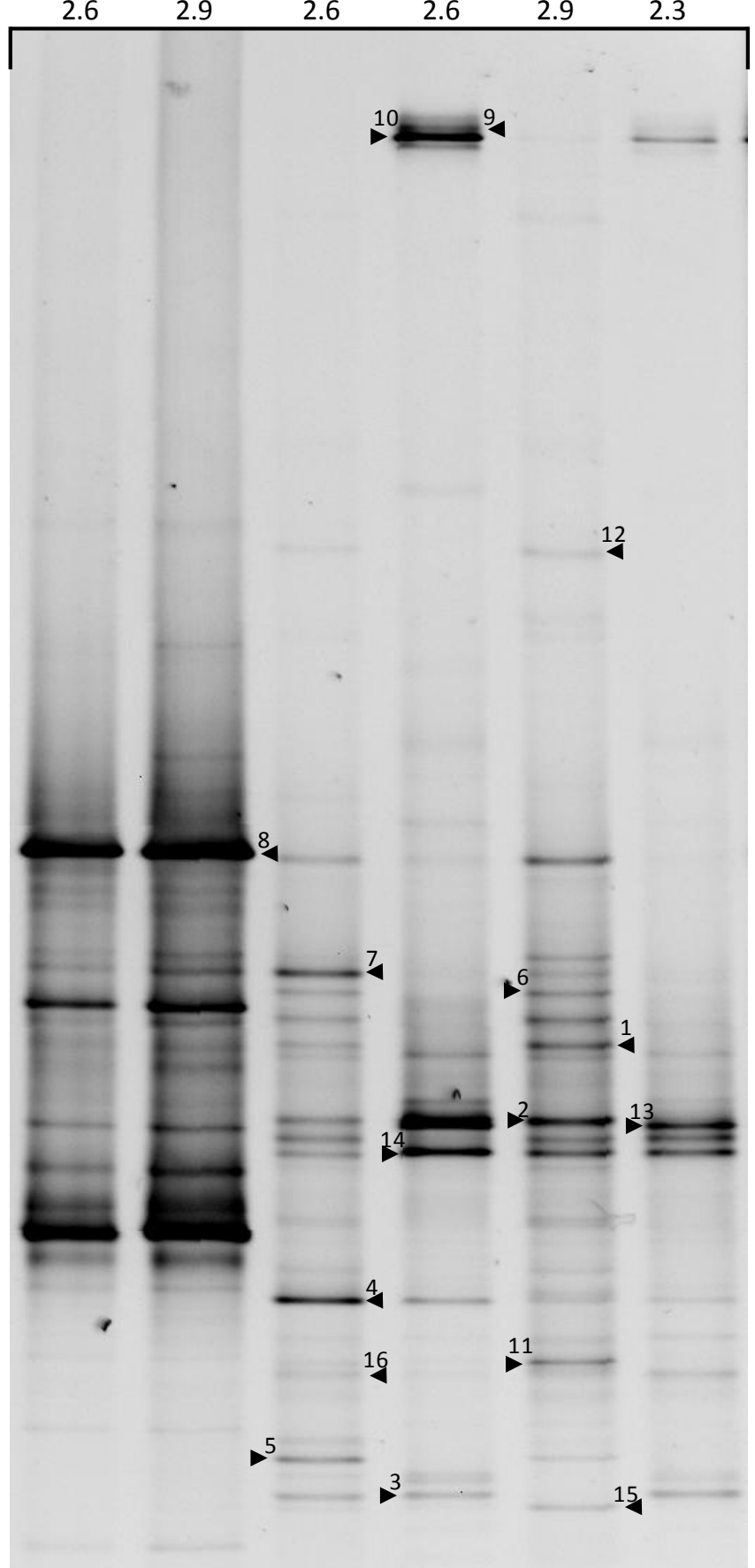


Table 1. RDP classification of the DGGE bands sequenced and corresponding matches (BLASTN) using the NCBI database with indication of the similarity percentages and sources of origin. The presence/absence of each band in each sample tested together with its intensity are also shown.

\begin{tabular}{|c|c|c|c|c|c|c|c|c|c|c|}
\hline $\begin{array}{l}\text { Taxonomic placement } \\
\text { ( } 50 \% \text { confidence level) }\end{array}$ & $\underset{n^{\circ}}{\text { Band }}$ & 1 & 2 & 3 & 4 & 5 & 6 & $\begin{array}{l}\text { Closest relatives in Blast } \\
\text { Name (accession number) }\end{array}$ & $\underset{(\%)}{\text { Similarity }}$ & Source of origin \\
\hline Phylum Proteobacteria & 1 & $\mathrm{x}$ & $x x$ & $x x$ & & $x x$ & & Uncultured delta proteobacterium (JN038629) & 89 & Soil \\
\hline Class Alphaproteobacteria & 2 & & & $\mathrm{xx}$ & $x x x$ & $x \mathrm{xx}$ & $\mathrm{xx}$ & Uncultured bacterium (JQ072580) & 90 & Brewery wastewater pilot reactor \\
\hline \multirow{2}{*}{\multicolumn{11}{|c|}{ Order Rhodospirillales }} \\
\hline & & & & & & & & & & \\
\hline Family Rhodospirillaceae & 3 & & & $\mathrm{x}$ & $x$ & $\mathrm{xx}$ & & Bacterium (AB208736) & 96 & Culture collection \\
\hline \multirow[t]{5}{*}{ Genus Azospirillum } & 4 & & & $x x x$ & $x x$ & $\mathrm{x}$ & $\mathrm{x}$ & Azospirillum fermentarium (NR_118484) & 99 & Nitrogen-fixing species \\
\hline & & & & & & & & Uncultured bacterium (JX174657) & 97 & $\begin{array}{l}\text { Microbial fuel cell fed with olive mill wastewater as sole } \\
\text { carbon source }\end{array}$ \\
\hline & 5 & & & $x x$ & & $\mathrm{x}$ & & Azospirillum sp.(HQ694759) & 99 & $\begin{array}{l}\text { Autotrophic enrichment culture En_UW_28 with } \mathrm{Na}_{2} \mathrm{~S}_{2} \mathrm{O}_{3} \\
\text { as electron donor }\end{array}$ \\
\hline & & & & & & & & Azospirillum brasilense (FR667883) & 99 & Culture collection \\
\hline & & & & & & & & Azospirillum sp. (AY061963) & 99 & Culture collection \\
\hline Order Rhizospirales & 6 & & & $x x$ & & $\mathrm{xx}$ & & Uncultured bacterium (FQ659151) & 90 & PAH degrading bacterial community in contaminated soil \\
\hline \multicolumn{11}{|l|}{ Family Xanthobacteraceae } \\
\hline \multirow[t]{2}{*}{ Genus Xanthobacter } & 7 & $\mathrm{x}$ & $\mathrm{xx}$ & $x \mathrm{xx}$ & $\mathrm{x}$ & $\mathrm{xx}$ & $\mathrm{x}$ & Xanthobacter sp.(HF566355) & 99 & Vineyard soil \\
\hline & & & & & & & & Xanthobacter flavus (AB512110) & 99 & $\begin{array}{l}\text { Polyvinyl alcohol-degrading bacteria from activated } \\
\text { sludge }\end{array}$ \\
\hline \multirow{2}{*}{\multicolumn{11}{|c|}{ Class Gammaproteobacteria }} \\
\hline & & & & & & & & & & \\
\hline \multicolumn{11}{|l|}{ Order Enterobacteriales } \\
\hline Family Enterobacteriaceae & 8 & $\mathrm{xxx}$ & $x x x$ & $\mathrm{xx}$ & $\mathrm{x}$ & $\mathrm{xx}$ & & Erwinia sp. (KF999718) & 99 & Extraction of Luffa cylindrica fruits \\
\hline \multicolumn{11}{|l|}{ Phylum Acidobacteria } \\
\hline & & & & & & & & & & \\
\hline \multicolumn{11}{|l|}{ Class Acidobacteria Gp4 } \\
\hline \multirow[t]{4}{*}{ Genus Blastocatella } & 9 & & & & $x \mathrm{xx}$ & & $\mathrm{x}$ & Uncultured bacterium (JX394456) & 98 & Aerosol microbiology in a metropolitan subway system \\
\hline & & & & & & & & Uncultured bacterium (DQ984629) & 98 & Oil-contaminated soil \\
\hline & 10 & & & & $x \mathrm{xx}$ & $\mathrm{x}$ & $\mathrm{xx}$ & Uncultured bacterium (JN603801) & 98 & Rhizosphere soil from field grown riceplants \\
\hline & & & & & & & & Uncultured bacterium (DQ984629) & 98 & Oil-contaminated soil \\
\hline \multicolumn{11}{|l|}{ Class Acidobacteria_Gp3 } \\
\hline \multirow[t]{2}{*}{ Genus Bryobacter } & 11 & $\mathrm{x}$ & $\mathrm{x}$ & $x$ & $x$ & $x x$ & & Uncultured bacterium (FQ659827) & 97 & $\begin{array}{l}\text { PAH degrading bacterial community of a contaminated } \\
\text { soil }\end{array}$ \\
\hline & & & & & & & & Uncultured bacterium (EF393024) & 97 & $\begin{array}{l}\text { Anaerobic polychlorinated biphenyl dechlorinating } \\
\text { consortia }\end{array}$ \\
\hline \multicolumn{11}{|l|}{ Class Holophagae } \\
\hline \multirow{2}{*}{\multicolumn{11}{|c|}{ Order Holophagales }} \\
\hline \multicolumn{2}{|l|}{ Family Halophagaceae } & & & & & & & & & \\
\hline Genus Geothrix & 12 & & & $x$ & & $\mathrm{x}$ & & Uncultured bacterium (KC758898) & 98 & Sulfate-reducing MTBE and TBA plume \\
\hline
\end{tabular}




\begin{tabular}{|c|c|c|c|c|c|c|c|c|c|c|}
\hline & & & & & & & & Uncultured Geothrix sp. (AJ583203) & 98 & $\begin{array}{l}\text { Ground water from a monitoring deep-well at a } \\
\text { radioactive waste disposal site }\end{array}$ \\
\hline & & & & & & & & Uncultured bacterium (JQ996662) & 98 & $\begin{array}{l}\text { Activated sludge in an anaerobic methane oxidation } \\
\text { reactor }\end{array}$ \\
\hline & & & & & & & & & & \\
\hline \multirow{2}{*}{\multicolumn{11}{|c|}{$\begin{array}{l}\text { Phylum Cyanobacteria/Chloroplast } \\
\text { Class Cloroplast }\end{array}$}} \\
\hline \multirow{2}{*}{\multicolumn{11}{|c|}{$\frac{\text { Class Cloroplast }}{\text { Family Chloroplast }}$}} \\
\hline & & & & & & & & & & \\
\hline \multirow[t]{4}{*}{ Genus Chlorophyta } & 13 & $\mathrm{xx}$ & $\mathrm{xx}$ & & $x x x$ & & $\mathrm{xxx}$ & Chlorella sorokiniana (KF981992) & 99 & Water \\
\hline & & & & & & & & Chlorella sorokiniana (KJ742376) & 99 & Culture collection \\
\hline & & & & & & & & Chlorella sp. (KM218897) & 99 & Coastal water \\
\hline & & & & & & & & Uncultured Chlorella (KC994689) & 97 & Microalgae photobioreactor \\
\hline \multirow{2}{*}{\multicolumn{11}{|c|}{ Phylum Ignavibacteriae }} \\
\hline & & & & & & & & & & \\
\hline \multicolumn{11}{|l|}{$\begin{array}{l}\text { Class Ignavibacteria } \\
\text { Order Ianavibacteriales }\end{array}$} \\
\hline \multicolumn{11}{|l|}{ Family Ignavibacteriaceae } \\
\hline \multirow[t]{3}{*}{ Genus Ignavibacterium } & 14 & & & $x x$ & $x x x$ & $\mathrm{xxx}$ & $x \mathrm{xx}$ & Uncultured bacterium (JX040332) & 99 & Waste water \\
\hline & & & & & & & & Uncultured sludge bacterium (FJ947134) & 98 & $\begin{array}{l}\text { Activated sludge in a livestock wastewater treatment } \\
\text { plant }\end{array}$ \\
\hline & & & & & & & & Uncultured bacterium (JQ624282) & 98 & Wastewater treatment plant \\
\hline \multirow{2}{*}{\multicolumn{11}{|c|}{ Phylum Actinobacteria }} \\
\hline \multirow{2}{*}{\multicolumn{11}{|c|}{$\begin{array}{l}\text { Class Actinobacteria } \\
\text { Subclass actinobacteridae }\end{array}$}} \\
\hline & & & & & & & & & & \\
\hline \multicolumn{11}{|l|}{ Order actinomycetales } \\
\hline \multirow{2}{*}{\multicolumn{11}{|c|}{$\begin{array}{l}\text { Suborder Corynebacterineae } \\
\text { Family Mycobacteriaceae }\end{array}$}} \\
\hline & & & & & & & & & & \\
\hline \multirow{3}{*}{ Genus Mycobacterium } & 15 & $x$ & $x$ & & $\mathrm{x}$ & & & Mycobacterium sp.( KJ729254) & 99 & Activated sludge from wastewater treatment plant \\
\hline & & & & & & & & Uncultured bacterium (HE965750) & 99 & $\begin{array}{l}\text { PAH-degrading bacteria isolated from oil-containing } \\
\text { sewage soil }\end{array}$ \\
\hline & & & & & & & & Mycobacterium gilvum (JN590246) & 99 & Oil-containing sewage soil \\
\hline Phylum Chloroflexi & 16 & & & $\mathrm{x}$ & $\mathrm{x}$ & $\mathrm{x}$ & $x$ & Uncultured Chloroflexi bacterium (FJ912105) & 91 & Marine sediment \\
\hline
\end{tabular}


404

405

406

407

408

409

410

411

412

421

\section{Conclusions}

This study confirmed the superior performance of bacterial and algal-bacterial airlift reactors over conventional biofilters for the removal of toluene, which achieved ECs up to $320 \mathrm{~g} \mathrm{~m}^{-3} \mathrm{~h}^{-1}$ at empty bed residence times of $1.1 \mathrm{~min}$. Biomass concentration and medium renewal rate played a key role on toluene abatement performance, with optimum values of $\sim 5 \mathrm{~g} \mathrm{~L}^{-1}$ and $0.45 \mathrm{~d}^{-1}$ (with a $90 \%$ biomass recycling), respectively. Moreover, photosynthetic activity in the photobioreactor resulted in lower emissions of $\mathrm{CO}_{2}$ and higher dissolved oxygen concentrations when suspended biomass was maintained below $5 \mathrm{~g} \mathrm{~L}^{-1}$, with higher values leading to mutual shading and therefore a low photosynthetic efficiency. The results also showed the positive impact of silicone oil addition on the stabilization of toluene biodegradation due to an enhanced $\mathrm{O}_{2}$ mass transfer and buffering against toxic metabolites. Finally, the presence of microalgae in the PB induced the enrichment of a microbial community different than that stablished in the $\mathrm{CB}$, as suggested by the low similarity observed between the microbial communities identified by the end of the operation and between the metabolites detected in the culture broth of both bioreactors.

\section{Acknowledgments}

This research was supported by MINECO (CTM2015-70442-R and Red Novedar) and the Regional Government of Castilla y León (Project VA024U14 and UIC 71). CONACyT-México is also gratefully acknowledged for the Master grant of Roxana Angeles.

\section{References}

American Water Works Association (2012) Standard methods for the examination of water and wastewater. American Water Works Association 1469. 
Bordel S., Muñoz R., Díaz L.F. and Villaverde S. (2007) Predicting the accumulation of harmful metabolic byproducts during the treatment of VOC emissions in suspended growth bioreactors. Environmental Science and Technology 41, 5875-5881.

Cheng Z., Lu L., Kennes C., Yu J. and Chen J. (2016) Treatment of gaseous toluene in three biofilters inoculated with fungi/bacteria: Microbial analysis, performance and starvation response. Journal of Hazardous Materials 303, 83-93.

Díaz L.F., Muñoz R., Bordel S. and Villaverde S. (2008) Toluene biodegradation by Pseudomonas putida F1: targeting culture stability in long-term operation. Biodegradation 19, 197-208.

EURAR-T, 2003. European Union Risk Assessment Report -Toluene (EINECS No. 203-6259), vol. 9, PL2.

Fu L.Y., Wu C.Y., Zhou Y.X., Zuo J.E. and Ding Y. (2016) Treatment of petrochemical secondary effluent by an up-flow biological aerated filter (BAF). Water Science and Technology, in press.

Gallastegui G., Barona A., Rojo N., Gurtubay L. and Elías A. (2013) Comparative response of two organic biofilters treating ethylbenzene and toluene after prolonged exposure. Process Safety and Environmental Protection 91, 112-122.

Häne B.G., Jäger K. and Drexler H.G. (1993) The Pearson product-moment correlation coefficient is better suited for identification of DNA fingerprint profiles than band matching algorithms. Electrophoresis 14, 967-972.

Harding R.C., Hill G.A. and Lin Y.H. (2003) Bioremediation of toluene-contaminated air using an external loop airlift bioreactor. Journal of Chemical Technology and Biotechnology 78, 406-411.

Jorio H., Kiared K., Brzezinski R., Leroux A., Viel G. and Heitz M. (1998) Treatment of air polluted with high concentrations of toluene and xylene in a pilot-scale biofilter. Journal of Chemical Technology and Biotechnology 73, 183-196.

Kuppardt A., Kleinsteuber S., Vogt C., Lüders T., Harms H. and Chatzinotas A. (2014) Phylogenetic and functional diversity within toluene degrading, sulphate reducing consortia enriched from a contaminated aquifer. Microbial Ecology 68, 222-234.

Lebrero R., Rodríguez E., Estrada J.M., García-Encina P.A. and Muñoz R. (2012) Odor abatement in biotrickling filters: Effect of the EBRT on methyl mercaptan and hydrophobic VOCs removal. Bioresource Technology 109, 38-45. 
Lebrero R., Rodríguez E., Pérez R., García-Encina P.A. and Muñoz R. (2013) Abatement of odorant compounds in one- and two-phase biotrickling filters under steady and transient conditions. Applied Microbiology and Biotechnology 97, 4627-4638.

Lebrero R., Hernández R., Pérez R., Estrada J.M. and Muñoz R. (2015) Two-liquid phase partitioning biotrickling filters for methane abatement: Exploring the potential of hydrophobic methanotrophs. Journal of Environmental Management 151, 124-131.

McDonald G (2003) Biogeography: space, time and life. Wiley, New York, p 409

McGinnis S. and Madden T.L. (2004) BLAST: at the core of a powerful and diverse set of sequence analysis tools. Nucleic Acids Research 32, W20-25.

Martin F., Torelli S., Le Paslier D., Barbance A., Martin-Laurent F., Bru D., Geremia R., Blake G. and Jouanneau Y. (2012) Betaproteobacteria dominance and diversity shifts in the bacterial community of a PAH-contaminated soil exposed to phenanthrene. Environmental Pollution 162, 345-353.

Muñoz R., Köllner C., Guieysse B. and Mattiasson B. (2004) Photosynthetically oxygenated salicylate biodegradation in a continuous stirred tank photobioreactor. Biotechnology Bioengineering 87, 797-803.

Muñoz R., Rolvering C., Guieysse B. and Mattiasson B. (2005) Photosynthetically oxygenated acetonitrile biodegradation by an algal-bacterial microcosm: a pilot-scale study. Water Science and Technology 51, 261-265.

Muñoz R. and Guieysse B. (2006) Algal-bacterial processes for the treatment of hazardous contaminants: A review. Water Research 40, 2799-2815.

Muñoz R., Daugulis A.J., Hernández M. and Quijano G. (2012) Recent advances in two phase partitioning bioreactors for the treatment of volatile organic compounds, Biotechnology Advances 30, 1707-1720.

Nagamani A., Soligalla R. and Lowry M. (2009) Isolation and characterization of phenol degrading Xanthobacter flavus. Bioremediation Journal 13, 1-6.

Quijano G., Rocha-Rios J., Hernández M., Villaverde S., Revah S., Muñoz R. and Thalasso F. (2010). Determining the effect of solid and liquid vectors on the gaseous interfacial area and oxygen transfer rates in two-phase partitioning bioreactors. Journal of Hazardous Materials $175,1085-1089$.

Roest K, Heilig H.G., Smidt H., de Vos W.M., Stams A.J.M. and Akkermans A.D.L. (2005) Community analysis of a full-scale anaerobic bioreactor treating paper mill wastewater. Systematic and Applied Microbiology 28, 175- 185. 
494

495

496

497

498

499

500

501

502

503

504

505

506

507

508

509

510

511

512

513

514

515

516

517

Sander R. (2014) Compilation of Henry's law constants, version 3.99. Atmospheric Chemistry and Physics Discussions 14, 29615-30521.

Semple K.T., Cain R.B. and Schmidt S. (1999) Biodegradation of aromatic compounds by microalgae. FEMS Microbiology Letters 170, 291-300.

Singh R.S., Rai B.N. and Upadhyay S.N. (2010) Removal of toluene vapour from air stream using a biofilter packed with polyurethane foam. Process Safety and Environmental Protection 88, 366-371.

Toledo F.L., Calvo C., Rodelas B. and González-López J. (2006) Selection and identification of bacteria isolated from waste crude oil with polycyclic aromatic hydrocarbons removal capacities. Systematic and Applied Microbiology 29, 244-252.

Vergara-Fernández A.O., Quiroz E.F., Aroca G.E. and Pulido N.A. (2008) Biological treatment of contaminated air with toluene in an airlift reactor. Electronic Journal of Biotechnology 11, $1-7$.

Wang Q., Garrity G.M., Tiedje J.M. and Cole J.R. (2007) Naive Bayesian classifier for rapid assignment of rRNA sequences into the new bacterial taxonomy. Applied and Environmental Microbiology 73, 5261-5267.

WHO (2000) Air Quality Guidelines, Regional Office for Europe, Denmark. Second Edition, Chapter 5.14

Yang Q., Xiong P., Ding P., Chu L. and Wang J. (2015) Treatment of petrochemical wastewater by microaerobic hydrolysis and anoxic/oxic processes and analysis of bacterial diversity. Bioresource Technology 196, 169-175.

Zhang L., Zhang C., Cheng Z., Yao Y. and Chen J. (2013) Biodegradation of benzene, toluene, ethylbenzene, and o-xylene by the bacterium Mycobacterium cosmeticum byf-4. Chemosphere 90, 1340-1347. 